\title{
Putative Rust Fungal Effector Proteins in Infected Bean and Soybean Leaves
}

\author{
Bret Cooper, Kimberly B. Campbell, Hunter S. Beard, Wesley M. Garrett, and Nazrul Islam
}

First, second, and third authors: Soybean Genomics and Improvement Laboratory, U.S. Department of Agriculture-Agricultural Research Service (USDA-ARS), Beltsville, MD 20705; fourth author: Animal Biosciences and Biotechnology Laboratory, USDA-ARS, Beltsville, MD 20705; and fifth author: Department of Nutrition and Food Science, University of Maryland, College Park 20742.

Accepted for publication 11 January 2016.

\begin{abstract}
Cooper, B., Campbell, K. B., Beard, H. S., Garrett, W. M., and Islam, N. 2016. Putative rust fungal effector proteins in infected bean and soybean leaves. Phytopathology 106:491-499.

The plant-pathogenic fungi Uromyces appendiculatus and Phakopsora pachyrhizi cause debilitating rust diseases on common bean and soybean. These rust fungi secrete effector proteins that allow them to infect plants, but their effector repertoires are not understood. The discovery of rust fungus effectors may eventually help guide decisions and actions that mitigate crop production loss. Therefore, we used mass spectrometry to identify thousands of proteins in infected beans and soybeans and in germinated fungal spores. The comparative analysis between the two helped differentiate a set of $24 \mathrm{U}$. appendiculatus proteins targeted for

secretion that were specifically found in infected beans and a set of 34 $U$. appendiculatus proteins targeted for secretion that were found in germinated spores and infected beans. The proteins specific to infected beans included family 26 and family 76 glycoside hydrolases that may contribute to degrading plant cell walls. There were also several types of proteins with structural motifs that may aid in stabilizing the specialized fungal haustorium cell that interfaces the plant cell membrane during infection. There were $16 P$. pachyrhizi proteins targeted for secretion that were found in infected soybeans, and many of these proteins resembled the $U$. appendiculatus proteins found in infected beans, which implies that these proteins are important to rust fungal pathology in general. This data set provides insight to the biochemical mechanisms that rust fungi use to overcome plant immune systems and to parasitize cells.
\end{abstract}

Obligate biotrophic rust fungi evolve as quickly as their hosts. This feature, inherent to their fitness, is problematic to agriculture where time and time again rust fungi overcome plant disease resistance genes (Johnson 1961). Rust fungal evolutionary attributes include both sexual and asexual life cycles, alternative or secondary host habitats, and the production of a diverse set of molecules that subvert plant immune systems and tilt plant biochemistry to favor fungal survival. Although scientists have fought rusts at the forefronts of life cycle stages and alternate host ranges (Roelfs 1982), the notion of circumventing the biochemical processes by which rusts overcome plant immunity captures the imaginations of many contemporary scientists these days.

The basic model for how rust fungi infect plants is an amalgam of what is known for rusts and other biotrophic and hemibiotrophic basidiomycete, ascomycete, and oomycete plant pathogens. Common to all cases is the observation that the pathogens secrete proteins to attach to leaves, to modulate cellular exterior surfaces, and to disable, disrupt, or evade host surveillance systems. For example, spores of the broad bean rust Uromyces viciae-fabae and wheat stem rust Puccinia graminis secrete proteins to anchor the spores to the leaf cuticle (Deising et al. 1992; Nirmala et al. 2011). The tubes that emerge from germinated spores, known as germlings, also secrete proteins as they migrate across a leaf surface (Epstein et al. 1987). Germlings then form appressoria that generate pressure to allow the fungus to enter the host apoplastic space by going through the stomata or by penetrating the epidermis directly

Corresponding author: B. Cooper; E-mail address: bret.cooper@ars.usda.gov

*The $\boldsymbol{e}$-Xtra logo stands for "electronic extra" and indicates that one supplementary table and one supplementary list are published online.

http://dx.doi.org/10.1094/PHYTO-11-15-0310-R

This article is in the public domain and not copyrightable. It may be freely reprinted with customary crediting of the source. The American Phytopathological Society, 2016.
(Edwards and Bonde 2011; Hoch et al. 1987). Either way, it is likely that proteins are secreted at this stage too, given evidence in Ustilago maydis (corn smut) and Colletotricum higginsianum (anthracnose) (Kleemann et al. 2012; Lanver et al. 2014). Once inside the leaf, rust fungi secrete proteins that allow them to breach the walls of the cells they infect (Rauscher et al. 1995). Afterward they secrete proteins through their haustoria that interface plant cells (Kemen et al. 2005). Haustoria are the conduits for nutrient acquisition (Voegele et al. 2001), but haustoria also allow rust fungi and other haustoria-producing microbes to pass proteins into a host to interrupt the host's immune system (Garnica et al. 2014).

An effector is a pathogen protein that contributes to a pathogen's virulence, and effectors can be secreted by rusts at any time during infection. The mechanism by which effectors are secreted from rust fungi is not understood, but we have tried to glean clues from Phytophthora spp. that also use haustoria to establish biotrophy. Downstream of a canonic amino-terminal signal that targets a Phytophthora effector for secretion is an Arg-X-Leu-Arg (RXLR) amino acid motif that allows the protein to be taken into the host (Whisson et al. 2007). Sequence surveys for this motif have identified hundreds of potential effectors in related Phytophthora spp. genomes (Jiang et al. 2008). The RXLR motif, however, has not been observed as readily in rust fungal proteins, and no other consensus motif has been identified that so easily distinguishes rust effectors or allows their entry into the host (Link et al. 2014; Puthoff et al. 2008; Rafiqi et al. 2010).

Few rust effectors have been characterized. Avirulence (Avr) proteins are a subclass of effectors defined by their elicitation of cognate resistance (R) proteins in plants (Flor 1971), and this straightforward definition has been used to describe a few flax rust secreted proteins as Avr effectors (Barrett et al. 2009; Catanzariti et al. 2006; Dodds et al. 2004). By contrast, the non-Avr effectors that by definition do not elicit $\mathrm{R}$ proteins are more difficult to identify. So far, evidence for gene expression in haustoria and protein transfer into plant cells are primary characteristics of nonAvr effector candidates. RTP from $U$. fabae was the first non-Avr 
rust fungal effector found to cross the haustorium into a plant cell (Kemen et al. 2005). RTP may be a cysteine protease inhibitor or may provide structural support for the haustorium (Kemen et al. 2013; Pretsch et al. 2013). The comparison of two rust fungal genomes revealed the prevalence of small, cysteine-rich, secretion signal-bearing proteins of unknown function which could comprise a set of non-Avr effectors (Duplessis et al. 2011). Four of these candidates from Melampsora larici-populina were shown to be expressed in infected plants and associate with infection hyphae and haustoria (Hacquard et al. 2012). Nonetheless, at least eight other M. larici-populina haustorium-expressed proteins without cysteinerich regions have been found to exhibit subcellular localization and protein-protein interactions in cells of the nonhost Nicotiana benthamiana (Petre et al. 2015). Hence, in vivo evidence of RNA and protein accumulation, not sequence feature inference, is driving effector discovery for rusts (Sperschneider et al. 2015).

The hunt to characterize effector proteins remains vigorous for rust fungi like $U$. appendiculatus, which infects beans, and Phakopsora pachyrhizi, which infects beans, soybeans, and kudzu. These rusts reduce the productivity of a staple food for indigent peoples and raise the costs of feed and oil sources for industrialized nations (Araya et al. 2004) (Kelly et al. 2015). Over the last 10 years, we have used mass spectrometry to identify proteins from beans and soybeans and from their respective rust fungi with an overall goal of mitigating production losses from rust diseases. Our research has led to the discovery of common bean and soybean proteins associated with resistance responses to $U$. appendiculatus and $P$. pachyrhizi infections (Cooper et al. 2011, 2013; Lee et al. 2009). We also have characterized the protein composition of $U$. appendiculatus uredospores and the changes in protein accumulation during uredospore germination (Cooper et al. 2006, 2007). To perform this research, we generated organism-specific cDNA sequence information that allowed us to interpret the tandem mass spectra (Link et al. 2014; Puthoff et al. 2008; Thibivilliers et al. 2009), but we also mined these sequences to identify candidate rust fungal effectors with signals targeting them for secretion (Link et al. 2014). During that time the genome sequences for soybean and common bean were resolved (Schmutz et al. 2010, 2014). Thus, we now can perform mass spectrometry on infected leaves, differentiate between plant and rust fungus peptide tandem mass spectra, and validate the existence of candidate effectors. So far, we have identified $58 \mathrm{U}$. appendiculatus candidate effectors from infected common bean leaves and 16 P. pachyrhizi candidate effectors from infected soybean leaves. These findings extend our knowledge of rust fungal proteins expressed in plants during infection.

\section{MATERIALS AND METHODS}

Inoculations. Two primary leaves of 10-day-old $P$. vulgaris 'Black Valentine' plants were sprayed with a liquid suspension of uredospores of $U$. appendiculatus race 41 (Cooper et al. 2007; Lee et al. 2009). The plants were placed in an $18^{\circ} \mathrm{C}$ dew chamber for $24 \mathrm{~h}$, and then moved to a $23^{\circ} \mathrm{C}$ growth chamber with fluorescent lighting. Inoculated leaves were harvested 6 days later, prior to the appearance of symptoms. One inoculated plant was kept as an indicator to ensure successful infection, which was measured as two to four pustules per leaf surface (square centimeter). Experiments in which indicator plants did not develop symptoms at 10 days after inoculation (DAI) or did not display desired infection density were abandoned. Three biological replicate experiments were performed at the USDA-ARS Soybean Genomics and Improvement Laboratory in Beltsville, MD.

The first trifoliate leaves on 3-week-old Glycine max 'Williams 82 ' were sprayed with a water suspension of uredospores of P. pachyrhizi clonal isolate Louisiana 4-1 (Cooper et al. 2011). The plants were placed in an $18^{\circ} \mathrm{C}$ dew chamber for $24 \mathrm{~h}$, and the inoculated leaves were harvested 7 days later. Inocula were adjusted to produce the highest possible density of pustules per trifoliate surface area. One inoculated plant was kept as an indicator to ensure successful infection. Experiments in which the indicator plants did not develop symptoms by 14 DAI or did not display desired infection density were abandoned. Three complete biological replicate experiments and subsequent protein preparations were performed at the USDA-ARS Foreign Disease-Weed Science Research Unit Biological Safety Level-3 Plant Pathogen Containment Facility at Ft. Detrick, MD, under the appropriate USDA-APHIS permit (Melching et al. 1983).

Protein preparation. Infected leaves were used to create soluble protein extracts (S30), extracts from crude membranes and organelles (P30), and extracts from cell walls (CW) (Lee and Cooper 2006; Lee et al. 2009). Leaves (4 g) were ground in liquid nitrogen and homogenized in a buffer $(100 \mathrm{mM}$ Tris- $\mathrm{HCl}, \mathrm{pH} 8.5$, $5 \mathrm{mM}$ dithiothreitol [DTT], $1 \mathrm{mM}$ ethylenediaminetetraacetic acid [EDTA], $1 \%$ plant proteinase inhibition mixture [Sigma-Aldrich, St. Louis, MO], and 1\% dodecyl-beta-maltoside [DBM]) with a glass grinder. The homogenate was centrifuged at $1,000 \times g$ for $10 \mathrm{~min}$, and the supernatant was centrifuged at $30,000 \times g$ for $1 \mathrm{~h}$ producing the P30 pellet and S30 supernatant. The S30 supernatant was filtered through a $0.45-\mu \mathrm{m}$ low protein retention polyvinylidene difluoride (PVDF) membrane (Millipore, Bedford, MS), and the protein was precipitated in $25 \%$ trichloroacetic acid (TCA) and acetone, washed in acetone and resolubilized in $8 \mathrm{M}$ urea/100 mM Tris- $\mathrm{HCl}, \mathrm{pH}$ 8.5. The $\mathrm{P} 30$ pellet was resuspended in homogenization buffer and triturated with a glass grinder. The mixture was incubated for $30 \mathrm{~min}$ with orbital shaking at 1,000 rpm and centrifuged at $1,400 \times g$ for $15 \mathrm{~min}$. The supernatant was retained and filtered through a $5 \mu \mathrm{m}$ PVDF membrane. The protein was TCA/acetone precipitated and resuspended in $8 \mathrm{M}$ urea/Tris- $\mathrm{HCl}$, $\mathrm{pH} 8.5$, plus $0.5 \% \mathrm{DBM}$ followed by sonication in a water bath for $20 \mathrm{~min}$. The $\mathrm{CW}$ pellet was created after grinding leaves in liquid nitrogen and buffer (8 M urea, $100 \mathrm{mM}$ Tris- $\mathrm{HCl}, \mathrm{pH} 8.5,5 \mathrm{mM}$ DTT, 1 mMEDTA, and 2\% DBM) and then with a glass grinder. The mixture was centrifuged at $1,000 \times g$ for $10 \mathrm{~min}$ and the pellet was washed four times in $100 \mathrm{mM}$ Tris- $\mathrm{HCl}, \mathrm{pH} 8.5,5 \mathrm{mM}$ DTT, and $1 \mathrm{mM}$ EDTA. CW proteins were extracted from the pellet (in $8 \mathrm{M}$ urea, $100 \mathrm{mM}$ Tris-HCl, pH 8.5, 5 mM DTT, 1 mM EDTA, and 2\% $\mathrm{DBM}$ ) by incubating the mixture for $20 \mathrm{~min}$ at room temperature, vortexing three times with 3 min intervals and then centrifuging at $1,400 \times g$ for $15 \mathrm{~min}$ at room temperature. The supernatant was retained and filtered through a $5 \mu \mathrm{m}$ PVDF membrane.

Asexual uredospores $(0.7 \mathrm{~g})$ for $U$. appendiculatus race 41 were germinated in $4 \mathrm{ml}$ of water in the presence of beta-ionone and Tween 20 in a glass dish in an $18^{\circ} \mathrm{C}$ dew chamber for $24 \mathrm{~h}$ (Cooper et al. 2007). The spores were examined by microscopy and collected if more than $50 \%$ had germinated. The germinated spores and the germination medium were brought to a final concentration of $100 \mathrm{mM}$ Tris-HCl, pH 8.5, $5 \mathrm{mM}$ DTT, $1 \mathrm{mM}$ EDTA, and 1\% proteinase inhibitor and were transferred to $2 \mathrm{ml}$ culture tubes containing $2.8 \mu \mathrm{m}$ ceramic beads. The contents were mixed in an Omni Bead Ruptor 24 (Omni International, Kennesaw, GA) for $75 \mathrm{~s}$ followed by three consecutive series of vortexing and ice incubation. The contents were centrifuged at $1,000 \times g$ for $10 \mathrm{~min}$ and filtered through a $5 \mu \mathrm{m}$ PVDF membrane, and the proteins were precipitated from the supernatant using TCA/acetone. Proteins were resolubilized in $8 \mathrm{M}$ urea/100 mM Tris- $\mathrm{HCl}, \mathrm{pH} 8.5$.

Protein concentrations were estimated by bicinchoninic assay (Pierce, Rockford, IL). Protein $(500 \mu \mathrm{g})$ from each fraction was reduced in tris(2-carboxyethyl)phosphine, carboxyamidomethylated with iodoacetamide, and digested with trypsin. The digested samples were desalted using solid phase extraction with SPEC-PLUS PT C18 columns (Varian, Lake Forest, CA).

Mass spectrometry. The peptide fractions were analyzed by biphasic liquid chromatography-tandem mass spectrometry, also known as MudPIT (Washburn et al. 2001; Wolters et al. 2001). The peptides were loaded off-line and then separated on-line on 
homemade biphasic columns prepared from $365 \mu \mathrm{m}$ (outer diameter) $\times 75 \mu \mathrm{m}$ (inner diameter) fused silica with a 5- $\mu \mathrm{m}$ tip and packed with $9 \mathrm{~cm}$ of reverse phase $\mathrm{C} 18$ resin (Aqua, $5 \mu \mathrm{m}$, Phenomenex, Torrance, CA) followed by $4 \mathrm{~cm}$ of strong cation exchange resin (Luna, $5 \mu \mathrm{m}$, Phenomenex). A 12-step elution procedure consisting of stepwise increasing concentrations of salt solution followed by increasing gradients of organic mobile phase was performed (Florens and Washburn 2006). Solvent flow was $200 \mathrm{~nL} / \mathrm{min}$ and was controlled with an Accela HPLC pump (Thermo Fisher Scientific, Waltham, MA) and a T-split junction where 2,100 V was applied (Florens and Washburn 2006). The eluent was electrosprayed directly into the orifice of an LTQOrbitrap XL mass spectrometer (Thermo Fisher Scientific) controlled by Xcalibur 2.0.7 software (Thermo Fisher Scientific). A parent-ion scan was performed in the Orbitrap over the range of 400 to $1,600 \mathrm{~m} / \mathrm{z}$ at 30,000 resolution with 500,000 automatic gain control (AGC), $500 \mathrm{msec}$ ion injection time, and 1 microscan. Lock-mass was enabled (Olsen et al. 2005). Data-dependent MS ${ }^{2}$ was performed in the linear ion trap with 10,000 AGC and $100 \mathrm{msec}$ ion injection times with $1 \mu \mathrm{scan}$. MS ${ }^{2}$ was performed on the 10 most intense MS ions, with minimum signals of $1,000 . \mathrm{MS}^{2}$ spectra were obtained using an isolation width of $2 \mathrm{~m} / \mathrm{z}$ and normalized collision energy of 35\%. Dynamic exclusion was used with repeat count of $2,30 \mathrm{~s}$ repeat duration, a list of 500, list duration of $2 \mathrm{~min}$, and exclusion mass width of $\pm 0.7 \mathrm{Da}$.

Peptide identification. $\mathrm{MS}^{2}$ spectrum data files were extracted from the raw data with Bioworks 3.3.1 (Thermo Fisher Scientific) using the following parameters: 600 to 4,500 mass range, 0 group scan, 1 minimum group count, and 5 minimum ion counts. MS ${ }^{2}$ spectra were searched with Mascot 2.5.1 (Perkins et al. 1999). Search parameters were for tryptic digests with one possible missed cleavage, fixed amino acid modification $[+57, \mathrm{C}]$, variable amino acid modification $[+16, \mathrm{M}]$, monoisotopic mass values, $\pm 10 \mathrm{ppm}$ parent ion mass tolerance, $\pm 0.8 \mathrm{Da}$ fragment ion mass tolerance and $\#^{13} \mathrm{C}=1$ enabled. The searched databases included version 1.0 protein models of $P$. vulgaris (31,638 sequences; https://phytozome. jgi.doe.gov/) plus alignment-oriented (Cooper et al. 2007) translated protein sequences derived from contiguous, overlapping expressed sequence tags from $U$. appendiculatus $(11,844$ sequences; [Link et al. 2014]), and version 6.0 protein models for G. $\max$ 'Williams 82' (55,787 sequences; https://phytozome.jgi.doe.gov/) plus alignmentoriented translated protein sequences derived from contiguous, overlapping expressed sequence tags from $P$. pachyrhizi (10,393 records; [Link et al. 2014]).

Mascot output files were processed by PANORAMICS ${ }^{2}$, a probability-based program that determines the likelihood that peptides are correctly assigned to proteins (Cooper et al. 2010; Feng et al. 2007). PANORAMICS ${ }^{2}$ considered peptide matches made by Mascot and for each calculated the probability that a peptide generated an observed spectrum. Analysis was limited to peptides having Mascot Ions score-Identity score differences not less than negative 5. PANORAMICS ${ }^{2}$ then calculated a probability that a protein was in a sample with respect to the selected database and the observed spectra. The probability that a protein was not identified by the peptide matches (false-positive rate) is 1 minus the calculated protein probability. Parsimony was achieved by grouping via protein probability calculations. For any protein group associated with multiple protein records, we chose the first record to represent the group, but retained the association to the other records. Peptide sequences reported here had Mascot expect values less than 0.05 (Supplementary Table S1).

\section{RESULTS}

Our objective was to identify $U$. appendiculatus candidate effectors in infected plants. Although proteins are secreted by rust fungi during numerous stages of infection, proteins secreted from haustoria are prime candidates for contributing to fungal virulence and biotrophy. There were 715 U. appendiculatus candidate secreted proteins derived from cDNAs sequenced from purified haustoria that were our targets (Link et al. 2014; Puthoff et al. 2008).

We examined $U$. appendiculatus race 41 on $P$. vulgaris 'Black Valentine'. We investigated a susceptible interaction rather than an avirulent/resistant interaction because we discovered that hypersensitive cell death and resistance severely limited the amount detectable fungal protein from avirulent strains (Lee et al. 2009). Therefore, the need to have detectable amounts of fungal protein drove our experimental decisions. At the same time, we also wanted to find haustorium proteins. Haustoria are produced within the first $24 \mathrm{~h}$ after inoculation, but it is difficult to find fungal proteins among plant proteins at that time (Lee et al. 2009). Hence, we sampled common bean leaves at 6 DAI knowing that we had missed the earliest steps of infection, but we still hoped to detect some important haustorial proteins secreted to maintain biotrophy.

Infected plant leaves were fractionated by differential centrifugation into crude cell wall $(\mathrm{CW})$, crude organelle and membrane (P30), and soluble components (S30) to increase the numbers and types of detectable proteins. Mass spectrometry analysis of these fractions yielded tens of thousands of tandem mass spectra matching peptides encoded by haustorial cDNAs and the genome of common bean (Link et al. 2014; Schmutz et al. 2014). We made no attempt to identify peptides using genome information from other rusts because sequence orthology has been insufficient for identifying $U$. appendiculatus effectors (Link et al. 2014). Peptide-spectrum matches were used in a probability model to identify proteins (Feng et al. 2007). Some peptides mapped to both a plant protein and a fungal protein, but we ignored such ambiguous identifications and instead focused on the distinct matches to rust fungal proteins (>95\% confidence).

We detected about 700 U. appendiculatus proteins among 2,500 total proteins in each $\mathrm{P} 30$ fraction, about $500 \mathrm{U}$. appendiculatus proteins among 1,800 total proteins in each S30 fraction, and about 200 U. appendiculatus proteins among 900 total proteins in each $\mathrm{CW}$ fraction. Thus, it appeared that about a quarter of all proteins we identified from infected beans were $U$. appendiculatus proteins. To better understand this proportion, we looked at the numbers of tandem mass spectra assigned to the proteins because the number of spectral observations for a protein (i.e., its summed spectral count) can correlate linearly with the amount of protein in a sample (Cooper et al. 2010). One bean protein that we expected to find in the S30 fraction was the cytosolic glutamine-dependent asparagine synthase 1 (Phvul.008G259900.1), and it had a spectral count of 126. Based on this marker, we defined highly abundant proteins as those having summed spectral counts greater than 100. By contrast, the $U$. appendiculatus asparagine synthase (Ua_contig04761) had a spectral count of 3 , which means that this protein was at the lower end of detectability. But not all rust fungal proteins had low abundance. $U$. appendiculatus elongation factor 1 -alpha (Ua_contig00283), one of the higher accumulating proteins in germlings (Cooper et al. 2007), had a summed spectral count of 125 in infected plants. Nevertheless, that was about 40 times less than the normalized spectral count for the highly abundant bean ribulose bisphosphate carboxylase small chain 1A. Similar observations were seen in the P30 fractions enriched for organelles where the bean photosystem I light harvesting complex gene 3 (Phvul.008G289700.1) had a summed spectral count of 166 , and the $U$. appendiculatus NADHubiquinone oxidoreductase (Ua_contig07133) had a summed spectral count of 25 . These examples are provided to generally demonstrate the range of abundances for the plant and fungal proteins. We concluded that it was more difficult to detect fungal proteins compared with plant proteins, and there may have been many fungal proteins below our limits of detection. Nevertheless, we assigned significance to the fungal proteins that were detectable above a plant protein background with the thought that there may be an association between detectability, abundance, and pathology. 
As mentioned earlier, there are multiple opportunities during the course of infection for rust fungi to secrete proteins. Therefore, we separately examined proteins isolated from purified, germinated race 41 spores and their germination water to help differentiate between $U$. appendiculatus proteins secreted from germlings prior to infection and proteins secreted during plant infection. The average number of germling proteins found was 1,300 , and about 90 proteins overall matched the candidate effector list for $U$. appendiculatus. Consequently, we were able to distinguish two categories of secreted bean rust proteins: (i) those found more than once in infected beans, but not in any of five germling analyses, and (ii) those found more than once in infected beans and at least once in five germling analyses. We assembled separate sets of data to address the hypotheses that germlings secrete some of the same effectors that haustoria do but that haustoria secrete unique effectors too.

Overall, 58 U. appendiculatus proteins found in infected plants matched the list of candidate secreted proteins (Tables 1 and 2, Supplementary List S1). Twenty-four of these $U$. appendiculatus proteins were not found in germlings, which implies that they were unique to plant infections and may therefore be haustorial specific
(Table 1). All but one could be matched to orthologs found in other rusts, but half of these matched proteins with no discernible function, and they had some of the weakest identities to other rust fungi homologs. This suggests that these proteins of unknown function are undergoing diversification particular to U. appendiculatus, and such evidence is thought to support the hypothesis that these proteins uniquely allow rusts to infect their adapted hosts (Catanzariti et al. 2006; Hacquard et al. 2012). Meanwhile, the more recognizable proteins included two RTP homologs and a PIG15p homolog. These are positive findings for this experiment since RTP is transferred from the haustorium into the plant cell, and PIG15p, which is partly similar to trehalose 6-phosphate synthase (Tps), localizes to the extrahaustorial matrix (Kemen et al. 2005). In addition to these proteins, we found two family 76 and two family 26 glycoside hydrolases. One of each was found in the S30 fractions whereas the others were found in the P30 fractions. This result suggests that these proteins may have different subcellular activities during infection. The three most abundant proteins overall were a chitinase, the PIG15p homolog, and a protein of unknown function (Ua_contig15794). At the other end of the spectrum, INF56, the gene of which is expressed after germling differentiation (Xuei et al. 1992), a pectinesterase family protein,

TABLE 1. Uromyces appendiculatus proteins targeted for secretion and found among three infected leaf analyses (CW, P30, and S30 leaf fractions) but not in five germling analyses (germ reps) ${ }^{\mathrm{a}}$

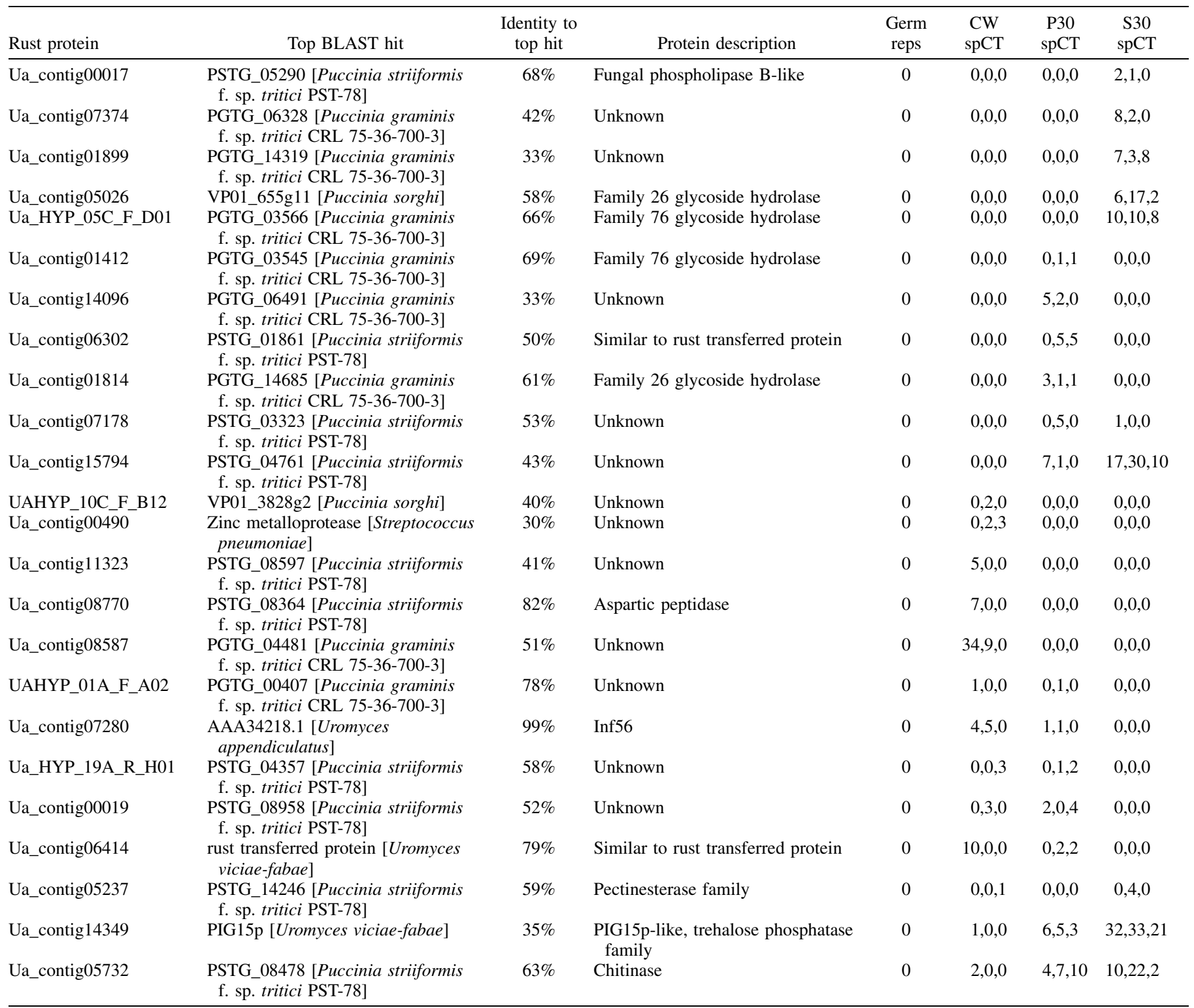

a The summed spectral count $(\mathrm{spCT})$ is shown for each replicate fraction. 
and a phospholipase B-like protein had only a few spectral counts and were not as readily detectable.

While some rust proteins appeared to uniquely accumulate in infected beans, there were 34 proteins found in both infected beans and $U$. appendiculatus germlings (Table 2). All of these proteins appeared to have homologs in other rust fungi, but seven had similarity to proteins with no discernible functions. As for the more recognizable proteins, three had peptidyl-prolyl cis-trans isomerase

TABLE 2. Uromyces appendiculatus proteins targeted for secretion and found among three infected leaf analyses (CW, P30, and S30 leaf fractions) and in germling analyses (germ reps) $)^{\mathrm{a}}$

\begin{tabular}{|c|c|c|c|c|c|c|c|}
\hline Rust protein & Top BLAST hit & $\begin{array}{l}\text { Identity to } \\
\text { top hit }\end{array}$ & Protein description & $\begin{array}{l}\text { Germ } \\
\text { reps }\end{array}$ & $\begin{array}{l}\mathrm{CW} \\
\mathrm{spCT}\end{array}$ & $\begin{array}{l}\mathrm{P} 30 \\
\mathrm{spCT}\end{array}$ & $\begin{array}{l}\mathrm{S} 30 \\
\mathrm{spCT}\end{array}$ \\
\hline Ua_contig01249 & $\begin{array}{l}\text { MELLADRAFT_123912 } \\
\text { [Melampsora larici-populina } \\
\text { 98AG31] }\end{array}$ & $71 \%$ & $\begin{array}{l}\text { FKBP-type peptidyl-prolyl cis-trans } \\
\text { isomerase domain }\end{array}$ & 3 & $0,0,0$ & $0,0,0$ & $2,4,0$ \\
\hline Ua_HYP_19C_R_A06 & $\begin{array}{l}\text { Peptide-methionine }(\mathrm{S})-\mathrm{S} \text {-oxide } \\
\text { reductase [Puccinia striiformis } \mathrm{f} . \mathrm{sp} \text {. } \\
\text { tritici } \text { PST-78] }\end{array}$ & $78 \%$ & Methionine sulfide reductase & 3 & $0,0,0$ & $0,0,0$ & $13,6,7$ \\
\hline Ua_contig00898 & $\begin{array}{l}\text { PSTG_01024 [Puccinia striiformis } \\
\text { f. sp. tritici } \text { PST-78] }\end{array}$ & $59 \%$ & Thioredoxin-like superfamily & 3 & $0,0,0$ & $1,3,0$ & $0,0,0$ \\
\hline Ua_contig01830 & $\begin{array}{l}\text { PSTG_03259 [Puccinia striformis } \\
\text { f. sp. tritici } \text { PST-78] }\end{array}$ & $75 \%$ & Serine carboxypeptidase & 3 & $0,0,0$ & $2,0,2$ & $0,0,0$ \\
\hline Ua_HYP_16D_F_B01 & VP01_2109g4 [Puccinia sorghi] & $60 \%$ & Unknown & 2 & $0,0,0$ & $0,2,3$ & $0,0,0$ \\
\hline Ua_contig06749 & $\begin{array}{l}\text { PGTG_07001 [Puccinia graminis } \\
\text { f. sp. tritici CRL 75-36-700-3] }\end{array}$ & $84 \%$ & Unknown & 1 & $0,0,0$ & $0,7,7$ & $0,0,0$ \\
\hline Ua_contig05181 & $\begin{array}{l}\text { PGTG_00638 [Puccinia graminis } \\
\text { f. sp. tritici CRL 75-36-700-3] }\end{array}$ & $64 \%$ & Unknown & 3 & $0,0,0$ & $1,3,0$ & $0,0,0$ \\
\hline Ua_contig04622 & $\begin{array}{l}\text { PSTG_14038 [Puccinia striiformis } \\
\text { f. sp. tritici } \text { PST-78] }\end{array}$ & $72 \%$ & FAD/NAD-binding domain & 1 & $0,0,0$ & $0,1,5$ & $0,0,0$ \\
\hline Ua_contig00583 & $\begin{array}{l}\text { PGTG_00454 [Puccinia graminis } \\
\text { f. sp. tritici CRL 75-36-700-3] }\end{array}$ & $98 \%$ & Prohibitin-2 & 2 & $0,0,0$ & $3,7,6$ & $0,0,0$ \\
\hline Ua_contig02338 & VP01_1064g7 [Puccinia sorghi] & $77 \%$ & Mitochondrial import receptor & 1 & $0,0,0$ & $3,6,8$ & $0,0,0$ \\
\hline Ua_HYP_18B_F_C09 & $\begin{array}{l}\text { PGTG_13504 [Puccinia graminis } \\
\text { f. sp. tritici CRL 75-36-700-3] }\end{array}$ & $78 \%$ & Unknown & 2 & $0,0,0$ & $4,8,5$ & $0,0,0$ \\
\hline Ua_contig08273 & $\begin{array}{l}\text { PGTG_14417 [Puccinia graminis } \\
\text { f. sp. tritici CRL 75-36-700-3] }\end{array}$ & $84 \%$ & Copper radical oxidase & 1 & $0,0,0$ & $3,7,3$ & $0,0,0$ \\
\hline Ua_contig05556 & $\begin{array}{l}\text { PSTG_04309 [Puccinia striiformis } \\
\text { f. sp. tritici } \text { PST-78] }\end{array}$ & $77 \%$ & Aspartic peptidase & 3 & $0,0,0$ & $2,5,3$ & $0,0,0$ \\
\hline Ua_contig01553 & $\begin{array}{l}\text { Hypothetical protein [Puccinia } \\
\text { striiformis f. sp. tritici] }\end{array}$ & $67 \%$ & Beta-Ig-H3/fasciclin domains & 3 & $0,0,0$ & $0,0,1$ & $6,6,0$ \\
\hline Ua_contig00456 & $\begin{array}{l}\text { PSTG_01749 [Puccinia striiformis } \\
\text { f. sp. tritici PST-78] }\end{array}$ & $81 \%$ & Peptidyl-prolyl cis-trans isomerase B & 3 & $0,0,0$ & $0,4,1$ & $8,5,3$ \\
\hline Ua_contig01113 & $\begin{array}{l}\text { PSTG_08709 [Puccinia striiformis } \\
\text { f. sp. tritici PST-78] }\end{array}$ & $66 \%$ & Unknown & 2 & $0,0,0$ & $0,1,0$ & $9,8,4$ \\
\hline Ua_contig01056 & $\begin{array}{l}\text { PSTG_01766 [Puccinia striiformis } \\
\text { f. sp. tritici } \text { PST-78] }\end{array}$ & $38 \%$ & Unknown & 3 & $0,0,0$ & $1,1,0$ & $6,6,2$ \\
\hline Ua_contig03019 & $\begin{array}{l}\text { PSTG_00066 [Puccinia striiformis } \\
\text { f. sp. tritici PST-78] }\end{array}$ & $93 \%$ & Karyopherin Kap95 nuclear import & 3 & $0,0,0$ & $0,5,4$ & $15,5,10$ \\
\hline Ua_contig10381 & $\begin{array}{l}\text { PSTG_01910 [Puccinia striiformis } \\
\text { f. sp. tritici } \text { PST-78] }\end{array}$ & $81 \%$ & Heat shock 90 family & 1 & $0,0,0$ & $1,0,3$ & $6,18,2$ \\
\hline Ua_contig06217 & VP01_2148g3 [Puccinia sorghi] & $82 \%$ & HSP70 actin superfamily & 3 & $0,0,0$ & $0,9,2$ & $0,3,0$ \\
\hline Ua_contig07202 & $\begin{array}{l}\text { PSTG_11377 [Puccinia striiformis } \\
\text { f. sp. tritici PST-78] }\end{array}$ & $62 \%$ & Glutathione-S-transferase family & 3 & $0,0,0$ & $4,1,1$ & $8,10,2$ \\
\hline Ua_contig01391 & $\begin{array}{l}\text { PGTG_14692 [Puccinia graminis } \\
\text { f. sp. tritici CRL 75-36-700-3] }\end{array}$ & $81 \%$ & $\begin{array}{l}\text { Secreted subtilisin-like serine } \\
\text { protease }\end{array}$ & 3 & $0,0,0$ & $7,3,6$ & $11,12,5$ \\
\hline Ua_contig01382 & $\begin{array}{l}\text { PGTG_08470 [Puccinia graminis } \\
\text { f. sp. tritici CRL 75-36-700-3] }\end{array}$ & $29 \%$ & Unknown & 1 & $2,0,0$ & $0,0,0$ & $0,0,0$ \\
\hline UAHYP_08C_F_A08 & $\begin{array}{l}\text { PGTG_07000 [Puccinia graminis } \\
\text { f. sp. tritici CRL 75-36-700-3] }\end{array}$ & $78 \%$ & $\begin{array}{l}\text { Phosphatidylglycerol/ } \\
\text { phosphatidylinositol transfer protein }\end{array}$ & 4 & $7,0,0$ & $0,0,0$ & $0,0,0$ \\
\hline Ua_HYP_25C_F_D02 & $\begin{array}{l}\text { PGTG_11656 [Puccinia graminis } \\
\text { f. sp. tritici CRL 75-36-700-3] }\end{array}$ & $64 \%$ & $\begin{array}{l}\text { Ser-Thr-rich glycosyl-phosphatidyl- } \\
\text { inositol-anchored membrane family }\end{array}$ & 1 & $6,0,0$ & $0,4,0$ & $0,0,0$ \\
\hline Ua_contig08119 & $\begin{array}{l}\text { PSTG_14392 [Puccinia striiformis } \\
\text { f. sp. tritici } \text { PST-78] }\end{array}$ & $92 \%$ & Peptidyl-prolyl cis-trans isomerase & 2 & $1,0,0$ & $1,0,0$ & $0,0,0$ \\
\hline Ua_HYP_06C_F_A11 & $\begin{array}{l}\text { PSTG_06116 [Puccinia striiformis } \\
\text { f. sp. tritici PST-78] }\end{array}$ & $60 \%$ & Disulfide isomerase & 1 & $3,0,0$ & $1,0,6$ & $0,0,0$ \\
\hline Ua_contig00065 & $\begin{array}{l}\text { Cytochrome } \mathrm{P} 450 \text { monooxygenase } \\
{[\text { Puccinia sorghi }]}\end{array}$ & $75 \%$ & Cytochrome P450 & 1 & $0,4,0$ & $6,5,4$ & $0,0,0$ \\
\hline Ua_contig00105 & $\begin{array}{l}\text { PGTG_17753 [Puccinia graminis } \\
\text { f. sp. tritici CRL 75-36-700-3] }\end{array}$ & $81 \%$ & Fumarate reductase & 3 & $0,1,0$ & $3,2,3$ & $0,2,0$ \\
\hline Ua_contig08573 & $\begin{array}{l}\text { PSTG_14661 [Puccinia striiformis } \\
\text { f. sp. tritici } \text { PST-78] }\end{array}$ & $54 \%$ & Fasciclin domain cell adhesion & 3 & $12,4,0$ & $2,2,2$ & $7,14,0$ \\
\hline Ua_contig04950 & $\begin{array}{l}\text { PSTG_09382 [Puccinia striiformis } \\
\text { f. sp. tritici PST-78] }\end{array}$ & $79 \%$ & $\begin{array}{l}\text { Family } 5 \text { glycoside hydrolase/ } \\
\text { mannosidase }\end{array}$ & 3 & $5,0,0$ & $10,0,2$ & $2,4,0$ \\
\hline Ua_contig00403 & VP01_2177g2 [Puccinia sorghi] & $51 \%$ & Mycelial surface antigen & 1 & $0,11,0$ & $4,4,4$ & $13,7,2$ \\
\hline Ua_contig06995 & $\begin{array}{l}\text { PGTG_05714 [Puccinia graminis } \\
\text { f. sp. tritici CRL 75-36-700-3] }\end{array}$ & $62 \%$ & Chitinase & 3 & $25,9,0$ & $15,18,20$ & $24,29,9$ \\
\hline Ua_contig05359 & $\begin{array}{l}\text { Glucose-regulated protein [Puccinia } \\
\text { graminis f. sp. tritici CRL 75-36- } \\
700-3]\end{array}$ & $95 \%$ & $\begin{array}{l}\text { Glucose regulated } 70-\mathrm{kda} \text { heat shock } \\
\text { bip-like }\end{array}$ & 3 & $10,39,14$ & $29,58,46$ & $52,62,10$ \\
\hline
\end{tabular}

${ }^{a}$ The summed spectral count $(\mathrm{spCT})$ is shown for each replicate fraction. 
domains, two had fasciclin domains, and seven had domains for sulfur and other oxidation/reduction activities. In addition, there were several peptidases and heat shock proteins. Similar proteins have previously been found in germinated $U$. appendiculatus spores (Cooper et al. 2007), but their orthologs have also been found in barley powdery mildew haustoria (Godfrey et al. 2009). Hence, these proteins may originate from haustoria, or from infection hyphae often copurified with haustoria, or both (Puthoff et al. 2008). On the other hand, a chitinase (different than the chitinase specific to infected beans), and a glucose-regulated $70 \mathrm{kDa}$ heat shock protein, the two most abundant candidate effectors found, seem more likely to originate from infection hyphae than haustoria because of their prevalence in germlings (Cooper et al. 2007). Nevertheless, these proteins may be secreted throughout the fungal life cycle. For example, it is possible that peptidyl-prolyl cis-trans isomerases and heat shock proteins found in both germlings and infected plants may need to be secreted to help proteins fold or regain their tertiary conformations, a requirement for proteins that are secreted from cells or transported through haustoria in denatured forms (Wang and Heitman 2005).

To better understand the relevance of these proteins as candidate effectors for bean rust infection, we performed a comparative analysis with virulent $P$. pachyrhizi isolate Louisiana 4-1 on susceptible G. $\max$ 'Williams 82'. Infected soybean leaves were sampled a day later than beans to follow a schedule favorable to experimentation within the containment facility at Ft. Detrick. There were 319 P. pachyrhizi candidate secreted proteins that were our targets (Link et al. 2014; Puthoff et al. 2008), and we discovered 16 proteins from this list (Table 3; Supplementary List S1). This is fewer than the number found for U. appendiculatus. Possible explanations for the difference could be a smaller biomass after infection relative to $U$. appendiculatus, one more day of $P$. pachyrhizi development, a smaller candidate list, or differential sample handling (in restrictive containment conditions by a technician other than the one who processed the beans). Nine of the proteins, however, were similar to U. appendiculatus proteins found in bean leaves. Fumarate reductase, disulfide isomerase, aspartic peptidase, and glucose regulated $70-\mathrm{kDa}$ heat shock protein have been found in P. pachyrhizi germlings (Luster et al. 2010) and orthologs for these proteins were found in $U$. appendiculatus germlings, which suggests that these proteins may be secreted during multiple stages of the soybean rust fungal life cycle. The chitinase, family 26 glycoside hydrolase and unknown protein Pp_contig04760 resembled orthologs found in U. appendiculatus-infected bean plants but not found in germlings. Therefore these proteins may be uniquely secreted during soybean rust infections. In summary, we have found that orthologous fungal proteins appear in plants infected by rusts of two different genera, Uromyces and Phakopsora. These findings support the hypothesis that these putative secreted proteins are generally important to rust fungal pathology and may therefore be effectors.

\section{DISCUSSION}

The identification of rust fungal effector proteins is one of the more daunting tasks in plant pathology, mainly because rust fungi cannot be cultured in vitro and are therefore not tractable to traditional genetics approaches to create mutant alleles. Nevertheless, there has been recent progress in rust fungal genetic transformation that exploits host resistance for selection (Lawrence et al. 2010). It is also possible to perform reverse genetics assays by expressing fungal genes in plants to induce gene silencing back to the rust fungus (Panwar et al. 2013a, b). Each method may lead to better ways to determine which genes encode effectors. But until these methods are refined and adapted for each rust fungus and plant system, the best way of determining whether a rust fungal protein is an effector is to monitor its biochemical activity in plants. One classical approach is to determine if a rust fungal protein is an Avr that elicits hypersensitive disease resistance (Catanzariti et al. 2006, 2010; Dodds et al. 2004, 2006; Nirmala et al. 2011). Not all effectors, however, are Avr proteins, so other techniques are needed to deduce their roles in pathogenicity and virulence. Methods include monitoring the passage of proteins from the fungus into the plant, finding their locations in a plant cell, and discovering their associations with plant proteins, be it in natural hosts or experimental surrogates. Such methods have been successfully used to identify effectors by a process of trial and error (Hacquard et al. 2012; Kemen et al. 2005; Petre et al. 2015; Rafiqi et al. 2010; Upadhyaya et al. 2014). We, however, have taken a different approach. By performing mass spectrometry on infected plant leaves, we have found 58 U. appendiculatus and 16 $P$. pachyrhizi candidate effector proteins. The cDNAs for these proteins encode signals targeting them for secretion, and the comparison between the candidate proteins found in germinated spores and those from infected plants suggests that a subset of the proteins may be specific to infected plants. It is therefore possible that a subclass of proteins defined here is secreted from differentiated fungal cells found in infected plants. Such cells may

TABLE 3. Phakopsora pachyrhizi proteins targeted for secretion and found among three infected leaf analyses (CW, P30, and S30 leaf fractions) ${ }^{\mathrm{a}}$

\begin{tabular}{|c|c|c|c|c|c|c|}
\hline Rust protein & Top BLAST hit & $\begin{array}{l}\text { Identity to } \\
\text { top hit }\end{array}$ & Protein description & $\begin{array}{l}\mathrm{CW} \\
\mathrm{spCT}\end{array}$ & $\begin{array}{l}\mathrm{P} 30 \\
\mathrm{spCT}\end{array}$ & $\begin{array}{l}\mathrm{S} 30 \\
\mathrm{spCT}\end{array}$ \\
\hline Pp_contig01910 & Ua_contig05026 (Table 1) & $43 \%$ & Family 26 glycoside hydrolase & $0,0,0$ & $0,0,0$ & $0,5,0$ \\
\hline Pp_contig00784 & Ua_HYP_08C_F_A08 (Table 2) & $65 \%$ & $\begin{array}{l}\text { Phosphatidylglycerol/phosphatidylinositol } \\
\text { transfer protein }\end{array}$ & $0,1,0$ & $0,0,0$ & $0,0,0$ \\
\hline PpGI_contig537 & VP01_673g2 [Puccinia sorghi] & $43 \%$ & Unknown & $0,2,0$ & $0,0,0$ & $0,0,0$ \\
\hline Pp_contig00105 & VP01_578g8 [Puccinia sorghi] & $58 \%$ & Mitofilin domain & $0,2,0$ & $0,0,0$ & $0,0,0$ \\
\hline Pp_contig01721 & $\begin{array}{l}\text { PSTG_04482 [Puccinia striiformis } \\
\text { f. sp. tritici PST-78] }\end{array}$ & $36 \%$ & Unknown/sbr82 & $0,3,0$ & $0,0,0$ & $0,0,0$ \\
\hline Pp_contig00888 & Ua_contig00105 (Table 2) & $85 \%$ & Fumarate reductase & $0,5,0$ & $0,0,0$ & $0,0,0$, \\
\hline Pp_contig06366 & $\begin{array}{l}\text { PGTG_13236 [Puccinia graminis } \\
\text { f. sp. tritici CRL 75-36-700-3] }\end{array}$ & $54 \%$ & Unknown & $1,2,0$ & $0,0,0$ & $0,0,0$ \\
\hline Pp_contig00934 & $\begin{array}{l}\text { MELLADRAFT_72534 [Melampsora } \\
\text { larici-populina 98AG31] }\end{array}$ & $81 \%$ & Calnexin & $0,1,0$ & $0,0,1$ & $0,0,0$ \\
\hline Pp_contig00374 & VP01_816g3 [Puccinia sorghi] & $63 \%$ & Phosphatidylethanolamine-binding domain & $0,3,0$ & $3,0,0$ & $0,0,0$, \\
\hline Pp_contig04760 & Ua_contig14096 (Table 1) & $39 \%$ & Unknown & $0,2,0$ & $3,2,2$ & $0,0,0$ \\
\hline PpGI_contig2186 & No match & 0 & Longest ORF 56-139, length 84, frame +3 & $4,6,2$ & $2,0,2$ & $0,0,0$ \\
\hline Pp_contig00004 & Ua_contig05359 (Table 2) & $89 \%$ & Glucose regulated $70-\mathrm{kda}$ heat shock bip-like & $10,10,0$ & $2,8,13$ & $0,0,0$ \\
\hline PpGI_contig2344 & Ua_contig00898 (Table 2) & $31 \%$ & Disulfide isomerase & $5,7,0$ & $0,0,0$ & $2,0,0$ \\
\hline Pp_contig01414 & Ua_HYP_06C_F_A11 (Table 2) & $61 \%$ & Disulfide isomerase & $21,5,4$ & $9,10,3$ & $7,0,5$ \\
\hline Pp_contig02895 & Ua_contig05556 (Table 2) & $67 \%$ & Aspartic peptidase/sbr15 & $17,0,7$ & $0,6,7$ & $7,16,12$ \\
\hline Pp_contig09994 & Ua_contig05732 (Table 1) & $47 \%$ & Chitinase & $15,1,12$ & $1,0,6$ & $0,11,6$ \\
\hline
\end{tabular}

a The summed spectral count ( $\mathrm{spCT})$ is shown for each replicate fraction. 
include appressoria, substomatal vesicles, infection hyphae, haustorial mother cells, and haustoria.

Mass spectrometry has been used before to identify rust fungal proteins in plants. Song et al. (2011) isolated P. triticina infection structures from wheat $6 \mathrm{DAI}$ and detected proteins targeted for secretion. These proteins included Tps, chitinases, glycosidases, peptidyl-prolyl cis-trans isomerases, disulfide isomerases, and several proteins of unknown function (Song et al. 2011). Our results generally overlap, which suggests that similar proteins from the evolutionarily related bean rust and soybean rust fungi are complicit to rust fungal pathology. For example, rust fungi must interface their haustorial membranes with plant cell membranes to establish biotrophy. Chitinases may allow the fungus to breach its own cell wall and expose the fungal membrane, while the family 26 and 76 glycoside hydrolases encompassing endo-1,4-beta-mannosidases and endo-alpha-mannanases, respectively, may help degrade plant cell walls or may modify proteins and small molecules linked to sugars.

The proteins that we have discovered may provide other insights into the mechanisms of fungal pathogenicity and biotrophy. Haustorium adhesion to a plant cell membrane may be accomplished with family 76 proteins (Kitagaki et al. 2002) and fasciclin domain proteins, which are also important for pathogenicity in ascomycete Magnaporthe oryzae (Bergstralh et al. 2015; Liu et al. 2009). The RTP homologs may play similar rolls in stabilizing haustorial membrane architectures (Kemen et al. 2013). The heat-shock proteins and peptidyl-prolyl cis-trans isomerase domain proteins may also help stabilize this interface or stabilize proteins that are transported across, while the proteins with oxidation/reduction activity may manage free radical generation that occurs during infection (Egan et al. 2007). Serine and aspartic peptidases may also regulate this interface or be translocated into the plant cell where they have specific activities that disrupt a plant's immune system (Zhu et al. 2004). The P30 membrane-localized prohibitin-2, a protein known to associate with mitochondria in animals, may regulate cell proliferation (Merkwirth and Langer 2009).

One of the more intriguing findings is the prevalence of the PIG15p homolog that has amino acid identity to Tps. Tps catalyzes the synthesis of trehalose, which can be converted into glucose, but Tps may have an alternate function in pathology not directly related to trehalose synthesis (Foster et al. 2003). In M. oryzae, Tps1 senses plant glucose-6-phosphate and activates glucose-6-phosphate dehydrogenase which converts NADP to NADPH, activating genetic switches to regulate separate pathways for carbon and nitrogen metabolism and virulence (Fernandez and Wilson 2011). In essence, the sensing of plant glucose-6-phosphate may signal to the fungus that it has breached the plant cell wall and that it is time for the fungus to deploy effectors and to assimilate plant nutrients (Badaruddin et al. 2013; Fernandez and Wilson 2012). It is possible that a similar process is happening in $U$. appendiculatus. Whether such a process is regulated by the PIG15p homolog remains to be determined. Doubt is cast because the PIG15p homolog is $75 \%$ smaller than Tps1, exhibits similarity to the carboxyl end of Tps1, and encodes a secretion signal whereas Tps does not. Thus, the role of this homolog in trehalose synthesis and glucose signaling is speculative, but its role in pathology appears to be important given its secretion signal and its greater prevalence for detection in infected leaves compared with germinated spores.

Although this study revealed many candidate effector proteins, there were several limitations. First, the candidate sequence databases that were used for peptide-spectrum matching did not represent the entire genomes for $U$. appendiculatus race 41 and $P$. pachyrhizi clonal isolate Louisiana 4-1. The data also comprised sequences from $U$. appendiculatus race SWBR1 and P. pachyrhizi isolates Taiwan 72-1 and Thai1 (Link et al. 2014; Posada-Buitrago and Frederick 2005; Puthoff et al. 2008). Hence, it is possible that not all of the effector genes specific to our isolates were among the lists we screened and that some of the true race 41 and isolate Louisiana 4-1 proteins are somewhat different from the protein sequences we used for spectrum matching. Second, we do not know if the putative secreted proteins we detected were actually secreted into the host, although we do know that they were expressed to high enough levels for detection during a period in which haustoria had formed. The detection of the RTP homologs, however, suggested we were close to target. Third, haustoria are not the only fungal cells that secrete effectors (Nirmala et al. 2011), but we believe that separate analyses of proteins from fungal germlings helped differentiate between proteins formed before and after haustorial formation and that some of the proteins we detected are reasonable candidates for being secreted from haustoria.

Several groups of scientists have sequenced cDNAs from fungal haustoria to identify effectors while others have bioinformatically mined genes to find candidates (Catanzariti et al. 2006; Duplessis et al. 2011; Godfrey et al. 2010; Hacquard et al. 2012; Hahn and Mendgen 1997; Hahn et al. 1997; Jakupovic et al. 2006; Link et al. 2014; Posada-Buitrago and Frederick 2005; Puthoff et al. 2008). These approaches share the common deficiency of not informing whether a protein is actually produced by its message during infection. With that in mind, one advantage of tandem mass spectrometry is that it provides direct evidence of protein translation. Even though we have not been able to search for all effectors for $U$. appendiculatus and $P$. pachyrhizi because their complete genome reference sequences are not yet known, tandem mass spectra are static representations of peptides found, and these spectra can be interrogated again when genomic blueprints are better resolved. Thus, we believe these tandem mass spectral data sets will remain useful for many more years to come. In the meantime, we will begin to investigate in greater detail some of the proteins we have found. It may be possible to test their functions in hosts and nonhosts by transient expression (Petre et al. 2015; Wang et al. 2006) or by host-induced gene silencing (Panwar et al. 2013a, b).

\section{ACKNOWLEDGMENTS}

We thank D. Luster for access to the plant pathogen containment facility at USDA-ARS, Ft. Detrick, MD; and X. Nou at USDA-ARS, Beltsville, $\mathrm{MD}$, for use of his Omni Bead Raptor. This research was funded entirely by the U.S. Department of Agriculture-Agricultural Research Service.

\section{LITERATURE CITED}

Araya, C. M., Alleyne, A. T., Steadman, J. R., Eskridge, K. M., and Coyne, A. P. 2004. Phenotypic and genotypic characterization of Uromyces appendiculatus from Phaseolus vulgaris in the Americas. Plant Dis. 88: 830-836.

Badaruddin, M., Holcombe, L. J., Wilson, R. A., Wang, Z. Y., Kershaw, M. J., and Talbot, N. J. 2013. Glycogen metabolic genes are involved in trehalose6-phosphate synthase-mediated regulation of pathogenicity by the rice blast fungus Magnaporthe oryzae. PLoS Pathog 9:e1003604.

Barrett, L. G., Thrall, P. H., Dodds, P. N., van der Merwe, M., Linde, C. C., Lawrence, G. J., and Burdon, J. J. 2009. Diversity and evolution of effector loci in natural populations of the plant pathogen Melampsora lini. Mol. Biol. Evol. 26:2499-2513.

Bergstralh, D. T., Lovegrove, H. E., and St Johnston, D. 2015. Lateral adhesion drives reintegration of misplaced cells into epithelial monolayers. Nat. Cell Biol. 17:1497-1503.

Catanzariti, A. M., Dodds, P. N., Lawrence, G. J., Ayliffe, M. A., and Ellis, J. G. 2006. Haustorially expressed secreted proteins from flax rust are highly enriched for avirulence elicitors. Plant Cell 18:243-256.

Catanzariti, A. M., Dodds, P. N., Ve, T., Kobe, B., Ellis, J. G., and Staskawicz, B. J. 2010. The AvrM effector from flax rust has a structured C-terminal domain and interacts directly with the $\mathrm{M}$ resistance protein. Mol. PlantMicrobe Interact. 23:49-57.

Cooper, B., Campbell, K. B., Feng, J., Garrett, W. M., and Frederick, R. 2011. Nuclear proteomic changes linked to soybean rust resistance. Mol. Biosyst. 7:773-783.

Cooper, B., Campbell, K. B., McMahon, M. B., and Luster, D. G. 2013. Disruption of Rpp1-mediated soybean rust immunity by virus-induced gene silencing. Plant Signal. Behav. 8:e27543.

Cooper, B., Feng, J., and Garrett, W. M. 2010. Relative, label-free protein quantitation: Spectral counting error statistics from nine replicate MudPIT samples. J. Am. Soc. Mass Spectrom. 21:1534-1546. 
Cooper, B., Garrett, W. M., and Campbell, K. B. 2006. Shotgun identification of proteins from uredospores of the bean rust Uromyces appendiculatus. Proteomics 6:2477-2484.

Cooper, B., Neelam, A., Campbell, K. B., Lee, J., Liu, G., Garrett, W. M., Scheffler, B., and Tucker, M. L. 2007. Protein accumulation in the germinating Uromyces appendiculatus uredospore. Mol. Plant-Microbe Interact. 20:857-866.

Deising, H., Nicholson, R. L., Haug, M., Howard, R. J., and Mendgen, K. 1992. Adhesion pad formation and the involvement of cutinase and esterases in the attachment of uredospores to the host cuticle. Plant Cell 4:1101-1111.

Dodds, P. N., Lawrence, G. J., Catanzariti, A. M., Ayliffe, M. A., and Ellis, J. G. 2004. The Melampsora lini AvrL567 avirulence genes are expressed in haustoria and their products are recognized inside plant cells. Plant Cell 16: 755-768.

Dodds, P. N., Lawrence, G. J., Catanzariti, A. M., Teh, T., Wang, C. I., Ayliffe, M. A., Kobe, B., and Ellis, J. G. 2006. Direct protein interaction underlies gene-for-gene specificity and coevolution of the flax resistance genes and flax rust avirulence genes. Proc. Natl. Acad. Sci. USA 103:8888-88893.

Duplessis, S., Cuomo, C. A., Lin, Y. C., Aerts, A., Tisserant, E., Veneault-Fourrey, C., Joly, D. L., Hacquard, S., Amselem, J., Cantarel, B. L., Chiu, R., Coutinho, P. M., Feau, N., Field, M., Frey, P., Gelhaye, E., Goldberg, J., Grabherr, M. G., Kodira, C. D., Kohler, A., Kues, U., Lindquist, E. A., Lucas, S. M., Mago, R., Mauceli, E., Morin, E., Murat, C., Pangilinan, J. L., Park, R., Pearson, M., Quesneville, H., Rouhier, N., Sakthikumar, S., Salamov, A. A., Schmutz, J., Selles, B., Shapiro, H., Tanguay, P., Tuskan, G. A., Henrissat, B., Van de Peer, Y., Rouze, P., Ellis, J. G., Dodds, P. N., Schein, J. E., Zhong, S., Hamelin, R. C., Grigoriev, I. V., Szabo, L. J., and Martin, F. 2011. Obligate biotrophy features unraveled by the genomic analysis of rust fungi. Proc. Natl. Acad. Sci. USA 108:9166-9171.

Edwards, H. H., and Bonde, M. R. 2011. Penetration and establishment of Phakopsora pachyrhizi in soybean leaves as observed by transmission electron microscopy. Phytopathology 101:894-900.

Egan, M. J., Wang, Z. Y., Jones, M. A., Smirnoff, N., and Talbot, N. J. 2007. Generation of reactive oxygen species by fungal NADPH oxidases is required for rice blast disease. Proc. Natl. Acad. Sci. USA 104:11772-11777.

Epstein, L., Laccetti, L. B., Staples, R. C., and Hoch, H. C. 1987. Cell-substratum adhesive protein involved in surface contact responses of the bean rust fungus. Physiol. Mol. Plant Pathol. 30:373-388.

Feng, J., Naiman, D. Q., and Cooper, B. 2007. Probability model for assessing proteins assembled from peptide sequences inferred from tandem mass spectrometry data. Anal. Chem. 79:3901-3911.

Fernandez, J., and Wilson, R. A. 2011. The sugar sensor, trehalose-6-phosphate synthase (tps1), regulates primary and secondary metabolism during infection by the rice blast fungus: Will Magnaporthe oryzae's "sweet tooth" become its “achilles' heel"? Mycology 2:46-53.

Fernandez, J., and Wilson, R. A. 2012. Why no feeding frenzy? Mechanisms of nutrient acquisition and utilization during infection by the rice blast fungus Magnaporthe oryzae. Mol. Plant-Microbe Interact. 25:1286-1293.

Flor, H. H. 1971. Current status of the gene-for-gene concept. Annu. Rev. Phytopathol. 9:275-296.

Florens, L., and Washburn, M. P. 2006. Proteomic analysis by multidimensional protein identification technology. Methods Mol. Biol. 328:159-175.

Foster, A. J., Jenkinson, J. M., and Talbot, N. J. 2003. Trehalose synthesis and metabolism are required at different stages of plant infection by Magnaporthe grisea. EMBO J. 22:225-235.

Garnica, D. P., Nemri, A., Upadhyaya, N. M., Rathjen, J. P., and Dodds, P. N. 2014. The ins and outs of rust haustoria. PLoS Pathog 10:e1004329.

Godfrey, D., Bohlenius, H., Pedersen, C., Zhang, Z., Emmersen, J., and Thordal-Christensen, H. 2010. Powdery mildew fungal effector candidates share N-terminal Y/F/WxC-motif. BMC Genomics 11:317.

Godfrey, D., Zhang, Z., Saalbach, G., and Thordal-Christensen, H. 2009. A proteomics study of barley powdery mildew haustoria. Proteomics 9: 3222-3232.

Hacquard, S., Joly, D. L., Lin, Y. C., Tisserant, E., Feau, N., Delaruelle, C., Legue, V., Kohler, A., Tanguay, P., Petre, B., Frey, P., Van de Peer, Y., Rouze, P., Martin, F., Hamelin, R. C., and Duplessis, S. 2012. A comprehensive analysis of genes encoding small secreted proteins identifies candidate effectors in Melampsora larici-populina (poplar leaf rust). Mol. PlantMicrobe Interact. 25:279-293.

Hahn, M., and Mendgen, K. 1997. Characterization of in planta-induced rust genes isolated from a haustorium-specific cDNA library. Mol. PlantMicrobe Interact. 10:427-437.

Hahn, M., Neef, U., Struck, C., Gottfert, M., and Mendgen, K. 1997. A putative amino acid transporter is specifically expressed in haustoria of the rust fungus Uromyces fabae. Mol. Plant-Microbe Interact. 10: 438-445.

Hoch, H. C., Staples, R. C., Whitehead, B., Comeau, J., and Wolf, E. D. 1987. Signaling for growth orientation and cell differentiation by surface topography in Uromyces. Science 235:1659-1662.
Jakupovic, M., Heintz, M., Reichmann, P., Mendgen, K., and Hahn, M. 2006. Microarray analysis of expressed sequence tags from haustoria of the rust fungus Uromyces fabae. Fungal Genet. Biol. 43:8-19.

Jiang, R. H., Tripathy, S., Govers, F., and Tyler, B. M. 2008. RXLR effector reservoir in two Phytophthora species is dominated by a single rapidly evolving superfamily with more than 700 members. Proc. Natl. Acad. Sci. USA 105:4874-4879.

Johnson, T. 1961. Man-guided evolution in plant rusts: Through his modification of the host plants of the cereal rusts, man is also modifying the rusts. Science 133:357-362.

Kelly, H. Y., Dufault, N. S., Walker, D. R., Isard, S. A., Schneider, R. W., Giesler, L. J., Wright, D. L., Marois, J. J., and Hartman, G. L. 2015. from select agent to an established pathogen: The response to Phakopsora pachyrhizi (soybean rust) in North America. Phytopathology 105:905-916.

Kemen, E., Kemen, A., Ehlers, A., Voegele, R., and Mendgen, K. 2013. A novel structural effector from rust fungi is capable of fibril formation. Plant J. 75:767-780.

Kemen, E., Kemen, A. C., Rafiqi, M., Hempel, U., Mendgen, K., Hahn, M., and Voegele, R. T. 2005. Identification of a protein from rust fungi transferred from haustoria into infected plant cells. Mol. Plant-Microbe Interact. 18:1130-1139.

Kitagaki, H., Wu, H., Shimoi, H., and Ito, K. 2002. Two homologous genes, DCW1 (YKL046c) and DFG5, are essential for cell growth and encode glycosylphosphatidylinositol (GPI)-anchored membrane proteins required for cell wall biogenesis in Saccharomyces cerevisiae. Mol. Microbiol. 46: 1011-1022.

Kleemann, J., Rincon-Rivera, L. J., Takahara, H., Neumann, U., Ver Loren van Themaat, E., van der Does, H. C., Hacquard, S., Stuber, K., Will, I., Schmalenbach, W., Schmelzer, E., and O'Connell, R. J. 2012. Sequential delivery of host-induced virulence effectors by appressoria and intracellular hyphae of the phytopathogen Colletotrichum higginsianum. PLoS Pathog. 8:e1002643.

Lanver, D., Berndt, P., Tollot, M., Naik, V., Vranes, M., Warmann, T., Munch, K., Rossel, N., and Kahmann, R. 2014. Plant surface cues prime Ustilago maydis for biotrophic development. PLoS Pathog. 10:e1004272.

Lawrence, G. J., Dodds, P. N., and Ellis, J. G. 2010. Transformation of the flax rust fungus, Melampsora lini: Selection via silencing of an avirulence gene. Plant J. 61:364-369.

Lee, J., and Cooper, B. 2006. Alternative workflows for plant proteomic analysis. Mol. Biosyst. 2:621-626.

Lee, J., Feng, J., Campbell, K. B., Scheffler, B. E., Garrett, W. M., Thibivilliers, S., Stacey, G., Naiman, D. Q., Tucker, M. L., Pastor-Corrales, M. A., and Cooper, B. 2009. Quantitative proteomic analysis of bean plants infected by a virulent and avirulent obligate rust fungus. Mol. Cell. Proteomics 8:19-31.

Link, T. I., Lang, P., Scheffler, B. E., Duke, M. V., Graham, M. A., Cooper, B., Tucker, M. L., van de Mortel, M., Voegele, R. T., Mendgen, K., Baum, T. J., and Whitham, S. A. 2014. The haustorial transcriptomes of Uromyces appendiculatus and Phakopsora pachyrhizi and their candidate effector families. Mol. Plant Pathol. 15:379-393.

Liu, T. B., Chen, G. Q., Min, H., and Lin, F. C. 2009. MoFLP1, encoding a novel fungal fasciclin-like protein, is involved in conidiation and pathogenicity in Magnaporthe oryzae. J. Zhejiang Univ. Sci. B 10:434-444.

Luster, D. G., McMahon, M. B., Carter, M. L., Fortis, L. L., and Nunez, A. 2010. Proteomic analysis of germinating urediniospores of Phakopsora pachyrhizi, causal agent of Asian soybean rust. Proteomics 10:3549-3557.

Melching, J. S., Bromfield, K. R., and Kingsolver, C. H. 1983. The plant pathogen containment facility at Frederick, Maryland. Plant Dis. 67:717-722.

Merkwirth, C., and Langer, T. 2009. Prohibitin function within mitochondria: Essential roles for cell proliferation and cristae morphogenesis. Biochim. Biophys. Acta 1793:27-32.

Nirmala, J., Drader, T., Lawrence, P. K., Yin, C., Hulbert, S., Steber, C. M., Steffenson, B. J., Szabo, L. J., von Wettstein, D., and Kleinhofs, A. 2011. Concerted action of two avirulent spore effectors activates reaction to Puccinia graminis 1 (Rpg1)-mediated cereal stem rust resistance. Proc. Natl. Acad. Sci. USA 108:14676-14681.

Olsen, J. V., de Godoy, L. M., Li, G., Macek, B., Mortensen, P., Pesch, R., Makarov, A., Lange, O., Horning, S., and Mann, M. 2005. Parts per million mass accuracy on an Orbitrap mass spectrometer via lock mass injection into a C-trap. Mol. Cell. Proteomics 4:2010-2021.

Panwar, V., McCallum, B., and Bakkeren, G. 2013a. Endogenous silencing of Puccinia triticina pathogenicity genes through in planta-expressed sequences leads to the suppression of rust diseases on wheat. Plant J. 73: 521-532.

Panwar, V., McCallum, B., and Bakkeren, G. 2013b. Host-induced gene silencing of wheat leaf rust fungus Puccinia triticina pathogenicity genes mediated by the Barley stripe mosaic virus. Plant Mol. Biol. 81:595-608.

Perkins, D. N., Pappin, D. J., Creasy, D. M., and Cottrell, J. S. 1999. Probability-based protein identification by searching sequence databases using mass spectrometry data. Electrophoresis 20:3551-3567. 
Petre, B., Saunders, D. G., Sklenar, J., Lorrain, C., Win, J., Duplessis, S., and Kamoun, S. 2015. Candidate effector proteins of the rust pathogen Melampsora larici-populina target diverse plant cell compartments. Mol. Plant-Microbe Interact. 28:689-700.

Posada-Buitrago, M. L., and Frederick, R. D. 2005. Expressed sequence tag analysis of the soybean rust pathogen Phakopsora pachyrhizi. Fungal Genet. Biol. 42:949-462.

Pretsch, K., Kemen, A., Kemen, E., Geiger, M., Mendgen, K., and Voegele, R. 2013. The rust transferred proteins-A new family of effector proteins exhibiting protease inhibitor function. Mol. Plant Pathol. 14:96-107.

Puthoff, D. P., Neelam, A., Ehrenfried, M. L., Scheffler, B. E., Ballard, L., Song, Q., Campbell, K. B., Cooper, B., and Tucker, M. L. 2008. Analysis of expressed sequence tags from Uromyces appendiculatus hyphae and haustoria and their comparison to sequences from other rust fungi. Phytopathology 98:1126-1135.

Rafiqi, M., Gan, P. H., Ravensdale, M., Lawrence, G. J., Ellis, J. G., Jones, D. A., Hardham, A. R., and Dodds, P. N. 2010. Internalization of flax rust avirulence proteins into flax and tobacco cells can occur in the absence of the pathogen. Plant Cell 22:2017-2032.

Rauscher, M., Mendgen, K., and Deising, H. 1995. Extracellular proteases of the rust fungus Uromyces viciae-fabae. Exp. Mycol. 19:26-34.

Roelfs, A. P. 1982. Effects of barberry eradication on stem rust in the United States. Plant Dis. 66:177-181.

Schmutz, J., Cannon, S. B., Schlueter, J., Ma, J., Mitros, T., Nelson, W., Hyten, D. L., Song, Q., Thelen, J. J., Cheng, J., Xu, D., Hellsten, U., May, G. D., Yu, Y., Sakurai, T., Umezawa, T., Bhattacharyya, M. K., Sandhu, D., Valliyodan, B., Lindquist, E., Peto, M., Grant, D., Shu, S., Goodstein, D., Barry, K., Futrell-Griggs, M., Abernathy, B., Du, J., Tian, Z., Zhu, L., Gill, N., Joshi, T., Libault, M., Sethuraman, A., Zhang, X. C., Shinozaki, K., Nguyen, H. T., Wing, R. A., Cregan, P., Specht, J., Grimwood, J., Rokhsar, D., Stacey, G., Shoemaker, R. C., and Jackson, S. A. 2010. Genome sequence of the palaeopolyploid soybean. Nature 463:178-183.

Schmutz, J., McClean, P. E., Mamidi, S., Wu, G. A., Cannon, S. B., Grimwood, J., Jenkins, J., Shu, S., Song, Q., Chavarro, C., Torres-Torres, M., Geffroy, V., Moghaddam, S. M., Gao, D., Abernathy, B., Barry, K., Blair, M., Brick, M. A., Chovatia, M., Gepts, P., Goodstein, D. M., Gonzales, M., Hellsten, U., Hyten, D. L., Jia, G., Kelly, J. D., Kudrna, D., Lee, R., Richard, M. M., Miklas, P. N., Osorno, J. M., Rodrigues, J., Thareau, V., Urrea, C. A., Wang, M., Yu, Y., Zhang, M., Wing, R. A., Cregan, P. B., Rokhsar, D. S., and Jackson, S. A. 2014. A reference genome for common bean and genome-wide analysis of dual domestications. Nat. Genet. 46:707-713.
Song, X., Rampitsch, C., Soltani, B., Mauthe, W., Linning, R., Banks, T., McCallum, B., and Bakkeren, G. 2011. Proteome analysis of wheat leaf rust fungus, Puccinia triticina, infection structures enriched for haustoria. Proteomics 11:944-63.

Sperschneider, J., Dodds, P. N., Gardiner, D. M., Manners, J. M., Singh, K. B., and Taylor, J. M. 2015. Advances and challenges in computational prediction of effectors from plant pathogenic fungi. PLoS Pathog 11: e1004806.

Thibivilliers, S., Joshi, T., Campbell, K. B., Scheffler, B., Xu, D., Cooper, B., Nguyen, H. T., and Stacey, G. 2009. Generation of Phaseolus vulgaris ESTs and investigation of their regulation upon Uromyces appendiculatus infection. BMC Plant Biol. 9:46.

Upadhyaya, N. M., Mago, R., Staskawicz, B. J., Ayliffe, M. A., Ellis, J. G., and Dodds, P. N. 2014. A bacterial type III secretion assay for delivery of fungal effector proteins into wheat. Mol. Plant-Microbe Interact. 27: 255-264.

Voegele, R. T., Struck, C., Hahn, M., and Mendgen, K. 2001. The role of haustoria in sugar supply during infection of broad bean by the rust fungus Uromyces fabae. Proc. Natl. Acad. Sci. USA 98:8133-8138.

Wang, L., Eggenberger, A., Hill, J., and Bogdanove, A. J. 2006. Pseudomonas syringae effector avrB confers soybean cultivar-specific avirulence on Soybean mosaic virus adapted for transgene expression but effector avrPto does not. Mol. Plant-Microbe Interact. 19:304-312.

Wang, P., and Heitman, J. 2005. The cyclophilins. Genome Biol. 6:226.

Washburn, M. P., Wolters, D., and Yates, J. R., 3rd. 2001. Large-scale analysis of the yeast proteome by multidimensional protein identification technology. Nat. Biotechnol. 19:242-247.

Whisson, S. C., Boevink, P. C., Moleleki, L., Avrova, A. O., Morales, J. G., Gilroy, E. M., Armstrong, M. R., Grouffaud, S., van West, P., Chapman, S., Hein, I., Toth, I. K., Pritchard, L., and Birch, P. R. 2007. A translocation signal for delivery of oomycete effector proteins into host plant cells. Nature 450:115-118.

Wolters, D. A., Washburn, M. P., and Yates, J. R., 3rd. 2001. An automated multidimensional protein identification technology for shotgun proteomics. Anal. Chem. 73:5683-5690.

Xuei, X., Bhairi, S., Staples, R. C., and Yoder, O. C. 1992. Characterization of INF56, a gene expressed during infection structure development of Uromyces appendiculatus. Gene 110:49-55.

Zhu, M., Shao, F., Innes, R. W., Dixon, J. E., and Xu, Z. 2004. The crystal structure of Pseudomonas avirulence protein AvrPphB: A papain-like fold with a distinct substrate-binding site. Proc. Natl. Acad. Sci. USA 101: 302-307. 